\title{
BEHAVIOR OF CONCRETE EXPOSED TO THE SEA \\ by
}

Bryant Mather

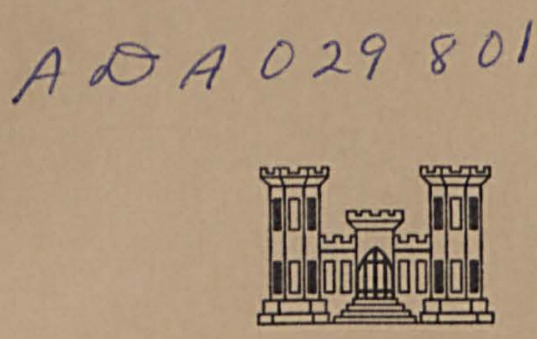

January 1970

Sponsored by

Office, Chief of Engineers

U. S. Army

Conducted by

U. S. Army Engineer Waterways Experiment Station CORPS OF ENGINEERS

Vicksburg, Mississippi

THIS DOCUMENT HAS BEEN APPROVED FOR PUBLIC RELEASE AND SALE; ITS DISTRIBUTION IS UNLIMITED 


\section{BEHAVIOR OF CONCRETE EXPOSED TO THE SEA}

by

Bryant Mather

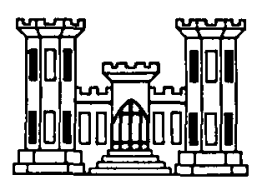

January 1970

Sponsored by

Office, Chief of Engineers

U. S. Army

Conducted by

U. S. Army Engineer Waterways Experiment Station CORPS OF ENGINEERS

Vicksburg, Mississippi

ARMY.MRC VICKBGURG, MISG.

THIS DOCUMENT HAS BEEN APPROVED FOR PUBLIC RELEASE

AND SALE; ITS DISTRIBUTION IS UNLIMITED 


\section{FOREWORD}

Under date of 24 December 1968, the Chief of Engineers informed the Director, Waterways Fxperiment Station (WES), that it was desired that representatives of the WES prepare a paper on any appropriate ocean engineering subject to be offered for inclusion on the program for the Conference on "Civil Engineering in the Oceans, II" to be held in Miami Beach, Florida, 10-12 December 1969, under the sponsorship of the Council on Ocean Engineering of the American Society of Civil Engineers. In accordance with this request, an abstract was prepared and forwarded to the program chairman for his consideration. Under date of 7 May 1969, advice was received that the paper on "Behavior of Concrete Exposed to the Sea" had been accepted. The paper was presented as the second paper in the Materials Session of the Conference, on 12 December 196. Copies have been furnished to the ASCE Technical Publications Department for inclusion in the proceedings of the conference. Copies were also furnished for review and approval to the Office, Chief of Engineers, and the paper was cleared for presentation and publication.

The paper is a summarization of relevant aspects of the state of knowledge in relevant areas.

COL Levi A. Brown was Director of the WES during the preparation of this paper and Mr. F. R. Brown was Technical Director. 


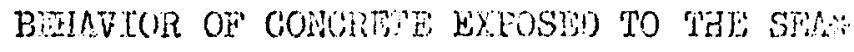

by

Bryent listher:-is

\section{INTRODUC'ITON}

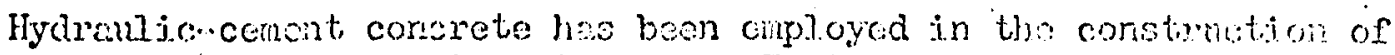

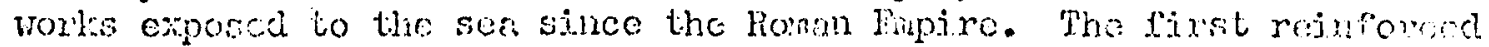
concrete structure made ueing portand cement is still in servico. Ju spite of this; long history of successful use, thure ure still instanows of concrote that undergoos severe detexioration and dostruction when exposed to the seo that rould have served setisfectoxily in a nonnexins? envizominent.

Rosearch on the factors affecting durability of concrete jn mand crposuras bis boen conducted at meny laboratories and has yictdon a bory of dita thet is satisfoctory to periti procticol messures to minimize.

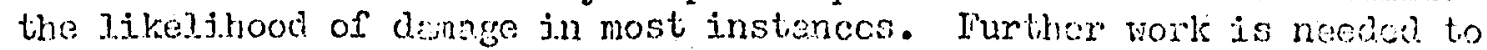
fully elucidats the interacting roles of vorious constituents of cant with the chloride and sulfate ions of set rater. Additional rosoricit is

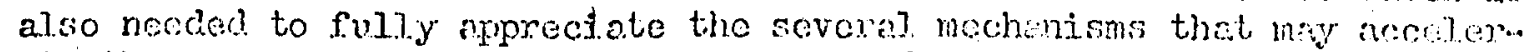
ate the corrosion of forrous metal crubeded in conclete cxposed to the sea. The use of porticand cencents containing less thum 8 porcont tri..colcium oluminate as calculated fom the chonical anelysis vil. normolly prevent deloterjous sulfate attack. Howevex, thore ero distinct indich. tions that coments with calculated tricalcjum aluminate contents appioch... jug zero are in some respects less desirable thon those in the intionmediate range botween zero and 8 percent. It is indicated that the bone.fi.ts of having some tricalcium aluminate mosenti are related to the tendency of this component to combine also vith chlorider and thus reduce the rate at wich chloride ions may bccome available et the intorface with reinforcing stee]. to pronote corrosion. Further research is iso necded to intorrelate the pluysical paraneters of pore structure as those control perinealizity and strength with the chemicsl parangters that. control the nature, anount, end rate of cormation of prociucts of in.creased volume thet generate internal expansion.

*Prepared for presontation at the Conforence on "Givil Fnginconing in

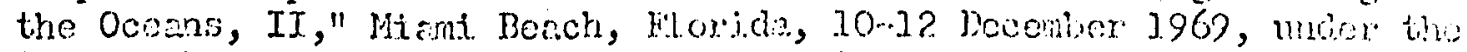
spensorship of the Couneit on Ocoen Histiecring of the Amerion Society of Civil. Jneineer's.

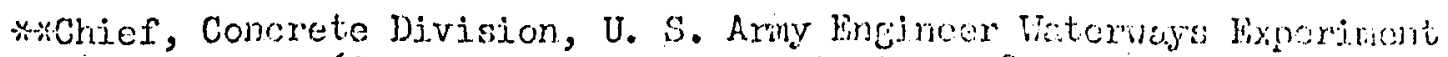
Station, Box 631, Viclebure, Miscissippi 39100 


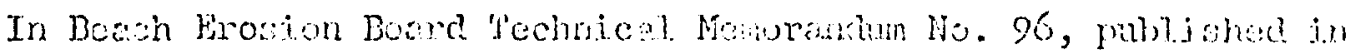
1957, a discussion was prosented of the "Factors Arfecting Lubilily of Concrete in Shore Structures" (Kather, 3.957). In 1.969 the Iroceedings of the RTLEH International Symposium on Muratidity of Constete were publjshed (RTIRA, 1.969) covering "Basic Qusstioni, Prinoiples and Method; of Testing and Determination of Concrete Mivebility under the Action of Frost, Sulfates, and Acids; and Corrosion of Reirforccment and Its Irevention." Prjor to 1957, betreon 1957 and 1969 , and in the future, these matters have been and will be urder further study throwh... out the world. When concrete does not behere satisfuctorily as a result of exposure to the sea the ciuse is, as is the cnse in all insterues of unsatisfactory performance, that the appropriate levels of ciuality wore not obtajned. The fajlure to obtain these levels of quality rosn].ts either from feilure to require them in specifications or failure in the execution of the work to comply with the specified requirements. Ience, the obtaining of satisfactory performance deponds upon: (a) an assess.ment of the perfumance requirements, (b) an evalustion of the crvixonmental influences, (c) an understanding of the results of researeh on the interrelation of environmental influences, quality levels, and achicved performence, (d) selection and specificition of relovent quality levels, and (e) insuring complinnce wjth specifjed requironentis.

\section{DHTERIORATIOIN-FPODUCING PHFINOHENA}

Many phenomena that contribute to the deterioration of concrete do so by mechanisms that induce internal expansion. That which expands inay be a constituent of the coment, a constituent of the aggregatc, or the contents of a pore or void in the concrete. These phenomena include: frost action, alkali-aggregate rcaction, sulfate attack, and i variety of chemical. reactions not involving alkiljes or sulfales. Similarly, deterioration may be induced by nonuniform contraction. Phenomena inducj.ng such contraction include drying and carbonation. Deterioration of concrete may occur due to solution and removal. by leaching of the soluble constituents of the cenent paste in the concrete. Daterioration of concrete may also occur as a secondary consequence of structural overlosding; that results from the interaction of external mechanical forces, such as those induced by foundation movements, seismj.c forces, and explosions. When concrete is found to have deteriorated following the occurrence of: such abnormal loadings of the structure in which the concrete was used, it is assumed that the deterioration is a secondary consequence of the structural failure that precedod or accompanied the deterioration. Such detcrioration can be avoided only by structural design to resjst the imposed loads. Cracking which occurs due to uncontrolled termperature variations in a structure does not of itself cause deterioration in the sense of this discussion, but it does increase the vulnerability to deterioration due to frost action or sulfate attack.

\section{PEPTINEIT FACTOSS IN A SEAVATER EXPOSUKI}

Concrete oxposed to seawater will be subjected to wetting by an aqueous solution containing princjpally dissolved sociun chloride and magnesium sulfite. The oceans contain, on the arecago, about 35 parts per thousand ( 3.5 percent) dissolved salts. The major caljons, Catt, $\mathrm{ME}^{++}$, $\mathrm{Na}^{++}$, and $\mathrm{K}^{+}$, exist in semater largely as uncomplexed species. 
Tho major allions include cj." which is also not strongly complexeci, and $\mathrm{CO}_{3-}=\mathrm{HCO}_{3-}^{-}$, and $\mathrm{SO}_{4}=$, which aro. Expressed as nij ligrons par liter of seamater, the principal. elements present in solution are clitorine, 19,000 ; sodium, 10,600; mignesiun, 1,300; sulfur, 900; cal cjum, 400; encl potassium, 380. Ajl other clements are probebly present, but no others make up more than $65 \mathrm{mg} / \mathrm{l}$. The six elements mentioned make up 99 porcent of the dissolved salts in sevwater. N though the concentration of dissolved solidis has been found to vary from pleace to plase, the ratio of any one of the major constituents to the totel dissolved solicks is nearly constant everythere (ACS, J.96/t).

Thus, the factors inherent in seawater exposure that should be considered for their effects on conerete are freozing and thaving, wetting and drying, and chemical reaction of chjorides, sulfates, alkalies (sodiun and potassium), ond, in some instances, dissolved carbon dioxicle.

The elements of concrete that may be affected by wetting or by chcmical reaction with chlorides, sulfeles, or alkalies include the comont, the asgeregates, and reinforcine stcel or other metal, if prescnt.

IEFEXIS OF CONTINUOUS IJTERSTON OF CONCREPY IN SEAWATER

Concrete that is totally and contimulus immersed in weten, even if the water contains dissolved salts such as are fourch in sonvater, general.. ly may be requrded as being in a protected exposure. Continuous immersion usually provicles a unifority of enviroment with respect to tomperature and moisture content that prevents the immersed concrete from bejng subjected to such deteriorating influences as frost ection, volume change due to wetting and drying, and differential volume chance due to moisture content differences between the surface and the interior. Continuous immersion also tends to reduce the potential for chonical reaction by re. moving changes in the degree of saturation as a mechanj.sm for the flow into and out of tho concrete of solutions containing ions capahle of at-tacking constituents of the concrete, and leaving only concentration gradients as the means of ingress of such ions. Locher and Pisters (196/) note that, under equal conditions of exposure, the aggressiveness of. water increases vi.th increasine concentration of the relevarit substances, but that agcressiveness is also increased by higher tomperatures, higher pressures, wetting and drying, or mcchanical abrosion by fast-flowing or turbulent waters.

\section{EEFECI'S OF JNTLRMTTWENT JMMIBRSTON OF CONCRETE IN SEAHATER}

Most concrete structures exposed to seavater are partially or wholly situated so that they are sometimes immersed in seavater and sometimes exposed to the oir. If the structure is located where the temperatures fall below freczing, the concrete exposed to the air with falling tide is probably subjected to as severe frost action as is any concrete in natural exposure. The realization that concrete exposed in the tidal zone in a rc-gion of low winter tomperatures would be subjected to very severe frost ac-tion resulted in the selection of the noan-tide elevation at Treat Island, Cobscook Eay, Me., as the location for the U. S. Army Cosps of Enginecrs severe natura weathering station. This location has becn used since 1936 
by the corps of lingineen to derelop informbtion rapidy on the relative resistance of concretes to frost action (Kennedy and Mather, 1953 ).

The sccond importent effect on concrete related to vetting and drying is the volurie change rolations due to changes in, or changes in uniformity of, mojsture content. These phenomena are often roferred to as drying shrinkage elfects.

In locilities such as Treat Island, the reen tompereture of the seavater is low and chemical reactions take place relatively slowly. Concretes relatively deficient in resistance to frost action sclam sur. vive long enough to manifust eny readily observable ofiects of chenical athack; hence, it con be argued that thore is a gonoral tendency for the severity of chemical athack to be reduced men thint of physical attick increases, and vico vorsa.

\section{CHEHTCAL ATTACK OF SENIATER OI CONORITTE}

The potentially agerossive constituents of someter vith respect to concrete axe the sulfate, chloride, carbonate, bjearbonate, alkali meter, and magnesjum ions. Since in secweter the sulfate componont. is manesium sulfate rather than sodiun or calciun sulfate, as is more often the case in sulfate-attack situatjons not involvine seavater, the various chemical reactions of magnesium surfate vith sciveral of the constitinents of hydrated portiand cenent are sonewhat different. F. H. Lea (1.956) pointed out that, initially, magnesium sulfate his a similar ection to that of other sulfates in attacling calciun alminate hydrate, but that later it can induce a significunty different and more farmeaching effect because of its ability-ms distinguished from other sulfatesto attack and dccompose the calciun silicate hydrate. Ihis rection proceeds to completion beceuse of the low solubility of megnesium hydroxicie.

The carbonate and bicarbonate ions my paticipato in the reaction of carbonation of celcium ion or calcium hylyoxide forined during hydration of cement. In a discussion of deterioration of collerete in the shipteys at Newport Nows, Va., Mrs. Terzaghi. (1948) concluded thet two processes were at work, one involving sulfate atteck that caused internal expansion and cracking, and the other involving carbon dioside dissolved in the water as carbonic ecid that caused local softcining and disintegration. The rater semples taken from relief wells in these shiprays were regirded as containing from 30 to 60 percent seewater, based on chlorjde content, and hid free $\mathrm{CO}_{2}$ contents of 7 to $97 \mathrm{mg} / 1$; the highest $\mathrm{CO}_{2}$ content wes found in tho sample of lowest searater content which hed $57 \mathrm{mg} / 1$ assressive $\mathrm{CO}_{2}$ and $a \mathrm{pH}$ of 6.9 .

Internal contraction due to carbonstion has been found to occur at the maximum rate and to the greutest extent when the concrete is subjected to an enviroment in which the relative humidity is close to 50 percont. Carbonation, like drying, is a phenonenon that proceeds from the surface invard and corsequently the degree to which a givon concrate element is affected over a given period of time docreases markedly with decrease of. surface:mass ritio. Carlson (1.937) hos shown that an occasional wetting of a concrete surface vil] prevent drying to a considerable depth beciuse 


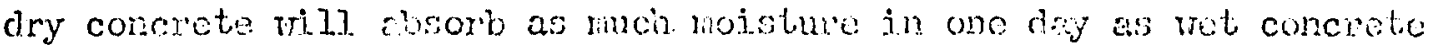
loses in tro veeks of drying: It is therefore concluded that dryingr shrinkege and cerborition sininkge re unlikely to be major sonrces of deterioration of concrete in the ocen. Apporent confuration of this conclusion is sugersted by the virting abonoe of ropots of such deteriom ration in the avalible literature. It is sucgested that conorete dotorioration in seexeter dine to these causes is largoly prociuded by the typical nature of the enviroment, the typically low sunfeceaniss ratio of the structural clementis inrolved, and the avojdance of materinls, pro. portions, and construction practjces that rould be condurive to develop. ment of this sont of deterioration, as thise ere avoiched for other reasons.

Alkalies

The a]lali metre ions mey priticipate in any of sovernl reations with reactive silice or reactive corbonate constibuntes of the agerogetso. Stanton (1937) listod enong structures advoroly rifectod by alkeli...jilica. reaction, soctions of secuells in Verture and Sonti? Parbera Countics in

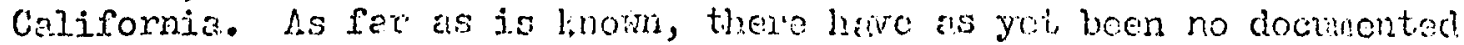
coses of alsali-cerbonato reation which heve consd deterioration of con

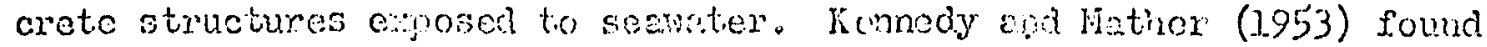
that in concrete contiuning a crushod linestone euregetic that had been

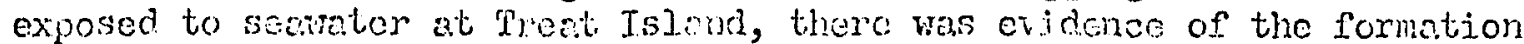
of renction rims on certuin limesion coursomagresate particlns. The particular Iinestone studied conteined about it percent of a montmorillom nitic clay wich undergoes grester suelting vion wited rith a solutjon containing sodium ion than when sclivi ion ju not present. They showed that this matorial, processod os mamiactured fine osgregrte, exhibitod two to three times as much increase ju volume when immersed in searater as when immersed in fresh valer of in a siturated solution of calcium hy. droxide. Buck and Nother (1969) describul on instince, believed to be the fjust of record, of detcrioration of collcrete due to aldati-sijicat reaction in which tho reactive aggregate res cuarta. Sinco the affectod structure was a dry dock at charlcston, S. C., jt was first assumed that the unusualnoss of the recction might have becn due tho the involvenent of seam water. However, the reaction product ves principslly a potassiun sil.jcate rather than a sodium silicato which indicatos that alkalies from the searater were not significantily jurolved. It was comeluded that the unusualness ras related to the physical rather than the chemical aspects of the enviroment.

Expansion of concrete caused by the swelling of the alkali-silica gel fomed in concrete by the reaction of alkali and soluble silica can normally be prevented in any of thrce vays. It can be prevented by the avoldance of the use of aggregate matorials containing soluble silica; or it can be prevented by the rostriction on the composition of the port.. land cenent with respect to alkali content so that the total amount of sodium oxide and potassium oxide, calculated as sodium oxide, does not exceed 0.60 percent; or fjnelly, it can be provonted by the use in the concrete of ecequate amounts of fincly divicled active silice introdncod in the forn of pozzolan. So fax an is knom, there hos baun no detcricration of concrete due to alkali-silica reaction in concrate in which any of the three preventive measures have been ciployed. Informal reports are rathar frequently encourtered that purjort to rafer to such deterioration in concrete made with lowmalkati conent. In ell of these 


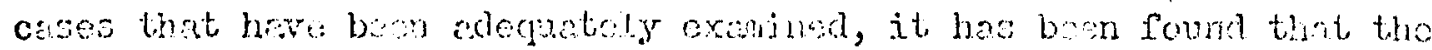

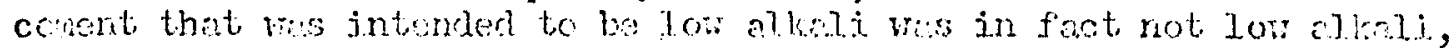

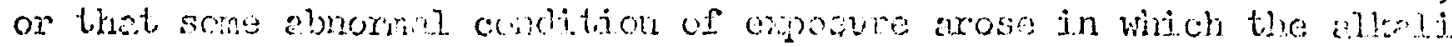
from e technically low-llew i conont wa presumb y so concentrated

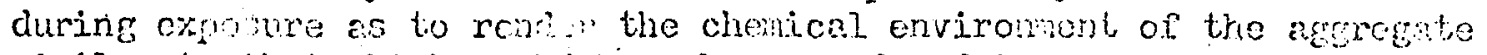
similer to that which would have been produced in a noro nomme eav ixon...

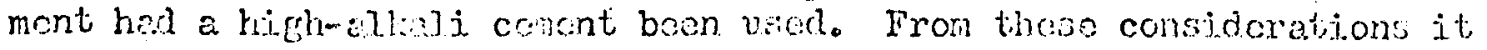

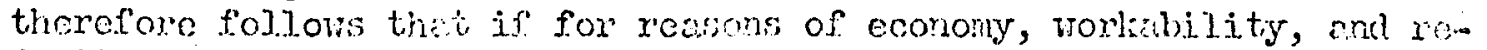
diction in heat erolution there are benefits to bo obtainced by the uso of substantial quantitics of chorically active porzol ans whercby ral, a. tively large quantitijes of finely divided soluble sijica are incorpon rated in the concrete, this practice rill. be beneficial in prevonting deterioration due to the alkelimilice resction.

\section{Chlorides}

The chloride ion my perticinate cither in chemicel reactions simi... lar to those involving the sulfito ion...so es to yield such products as

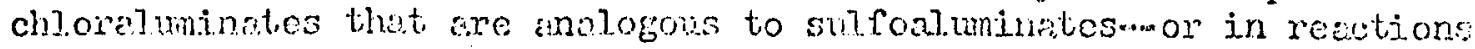
involving the corrosion of reinforcing or other ombecides netel. In this

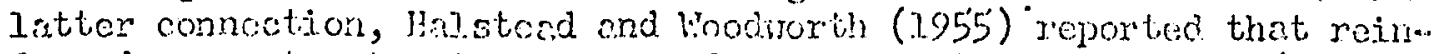
forcen concreto structures exposed under coastal conditions (within 10 mi. of the seccosst) in South hfuica have, in sone coses, shom deterioration believed coused by electrochemicel corrosion of the stcel. In the discussion of their poper, it was noted that the South Aficicon Railwar Adminjstration has adopted the policy of using reinforced concrete strucm tures in preference to steel because of difficul bies in mejntainines seol. structures. This agency also has attempted to design strvetures for a ninimum of reinforcing steel. The performence of such struetures hos garerelly been good, and such detexioration as has occurred is believed related to insufficient conerets covor over reinforcing steel that perm mitted corrosion to occur.

The role of chloridos in seaviter in chemicrintaration with concrete is twofold. Chlorides act inclependently to do those things that chlorides are capsble of dojng, and they also teid to retard or inlibit the action of sulfaies. The presence of chlorides, as in seanater, rotards or inhibits the expension of concrete by sulfate solutions, bit not the degree of reaction. Jea (1956) cited tile rork of Betta, who a.tributed this effect to the greater solubility of gypsum and calcium aluminum sulfate in chloride solutions, and it is the reason why friluro arising from chemjcal attack by scaweter is not preceded by sueliting to the same degree as in solutions of sodium or megnesjum sulfate.

Griffin and Herry (196/l) studied, separately, the affects of sodiun chloride and scawater salts in concrete. Their purpose was to deteinine the effect of sed-salt spray on concrete and the pormissible chounts of salt in concrete when it is mixed. They found thit the optimun salinity of mixing water for meximum compressive strength wes from 18 to $36 \mathrm{~g} / \mathrm{kg}$ when sodium cliloride was used end up to $88 \mathrm{~g} / \mathrm{kg}$ men sea se] t was used. They also fout that, whon sodivil chloride was used, the rate of mojeture migration thrcugh concrete from a region of highor to ons of lower rela. tive humidity decreased with increaving seljunity of mixing weter to $a$ salinity of akout $70 \mathrm{~g} / \mathrm{hg}$ and then remaisud relatively constent rith 


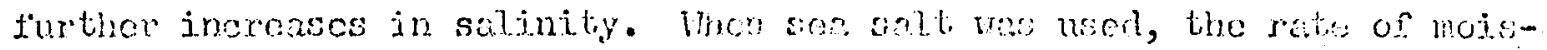

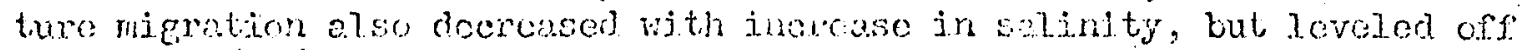
at ebout $25 \mathrm{~g} / \mathrm{kg}$.

They concluded that sone salt my bo bonefiein to concrete jo some respects. Tith a mixing rator 301 ini ly of bout $25 \mathrm{~g} / \mathrm{kg}$, strousth wos improved, the rate of moisture movent was reduced and corrosion of mild stcel in the Jow-strength concrets ured in their investigation was negrigible. With sodium chlorids, the maximuin corrosion of mild sted appoured to teke place at a salinity of chout $70 \mathrm{~g} / \mathrm{kg}$. It should porm haps be emphasized that Griffin and Henry vore studying the "pexninsible amounts of selt" that, could be tolcreted; j.t js not, $T$ belicve, their. intent to sugest that ono would deliborately ald salt to reinforect conesete jif it coulcicedily be avojded.

\section{FROST ACITOS}

In regions were concrete in service is subjoctcd to the action of freering and thewing, probably the principal fochor that has pirodued do terioration is frost action. Frost action produces cotorioration wien pores in the concrete, laree crough to contain fioezable water, bocone criticolly fjilled end the water freczes fastex thon j.t cin be expelled from the pore. Porcs thit can contain freezable vater are present in

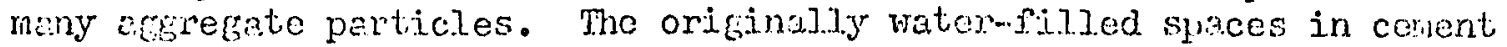
piste are also poras thet can contain froezable vetor. If deteriorition. due to freszing of freezoble whior in pores in agrrogate particles is to be avoided, precautions must be taken cither to avoid use of aggregate having such pore spaces or to avojd the development of critical satura.. tion in the pore spaces. Deterioration of concrete due to freezing of freczable water in the cenent poste can be avoided by providing the paste vith an approuniate air-void system and by protecting the concrete from freezing until hydration of the cenentiljous materjals has rocuced the volune of freezible water in the paste to the amount then can freeze without demage.

The use of aegregate selection criteria such as those regularly em.ployed by the major agencies in the United States, the nardatory use of aj.r-entraining adrixtures or airmentrajnjng cements meeting the applicable requirements of current nitionally establisied specifications for such products, and the control of concrete batching, mixing, and placing so as to ensure a proper air-void systeil in the hardened concrete vill successfully prevent deterioration of concrete resulting from the uptake of moisture, the achievenent of critical saturation in the susceptib]e pore spece, and the subsequent intermal expansion when the water freezcs.

\section{LESCHTNG}

Concrete can deteriorate by having its soluble constituents dis.. solved and reinoved by solvents that percolate through it. The degrec to which soluition and removal will occur depends on the rate at which the solvents rove through the concrets, the solubility of the soluble constituents, and the solvent porer of the solverit. One a the solvent has dissolvod all of the solvble meterial it can hold in solution, its 
further movenent through the concute will dissolve and remove no additionel materinl. If the solvent $j$ s saturated or nearly saturatod before it enters the concuete, il will dissolve no material or a very sirell anount of material as it traverses the concrote. The most ef fective mesns of preventing detorioration by leaching is to onsure that the concrete has a low permeability. Porers, Copelend, and Man (1959) shored that capillary continuity of conent postes can be proventod and pormeability consequently reduced greatly by use of low waterwecment ratios and proper curing. Their dat: show that moist-cured ceiient pastes lose capillaxy continuity after curing periods sowewhat as follons:

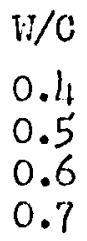

TTME REQUIRED

$$
\begin{aligned}
& 3 \text { days } \\
& 14 \text { deys } \\
& 6 \text { months } \\
& 1 \text { year }
\end{aligned}
$$

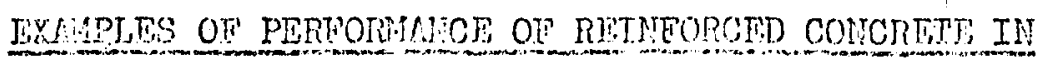

\section{FARTIMYE EXOSURIS}

Wentwouth-shiej.ds (1.956) described the first maritima reinforced concrete structure in Great Britain, constructed at southempton in 1899 , and. noted that very for failures have occurred. The 1899 structure was a jetty consisting of a 100. by 40.rt deck on piles. In 1.902, Town euny, a reinforced concrete structure 360 by 20 by $34 \mathrm{ft}$ hi.gh, was built at south hampton. A fer years later longitudinal cracks appeared above the meanticic level along lines of reinforcenent, due to rusting of steel. Repairs were mede with pneunatically applicd mortar. The rusting of the steel has been ascribed to the perneabili.ty of the concrete, but in the case of T'own Quay electiolytic action was, if not the sole couse, a very imm portant contributory cause. The 1899 structure, which is stijl in excellent condition, was made with dry, low water-coment ratio concrete; the 1902 one was made with a "rather vet" mixture.

Not only is the first maritine reinforced concrete stmucture built in Great Britain still in excell.ent condition, but most concrete structures in seawater exposures are in good condition when good practice wes used and care was taken in their design and construction. For example, the concrete ship "Atlantus," the first constructed by the United States Government, was launched in 1918. It wes brought to Cape May, N. J., to serve as a terminal for a ferry line and in 1927 became stranded on a sandber. It was inspected at various times between 1918 and 1930. A report on its trial run in 1919 fron Brunstrick, Gao, to Charleston, S. C., states that the concrete vas "in a practically perfect state of preservotion with no important rust stains visible, a.though there could be traced in certain places on the hull the faint markings of hatiline cracks which peralleled the system of reinforcing closest to the outcr surface." We].ter, in 1929, published a photograph of a specimen of concrete taken from the ship. in 1928 showing the imprint of a square bar $13 / 16$ in. and a round bar 5/16 in. from the outer exposed surface of the concrete, and stated that the steel was not corroded. Arter an exonination of the ship in J328, it was reported that a very presouriced rust stain had developed in the bulkhead enclosing the afterqunters, and in 


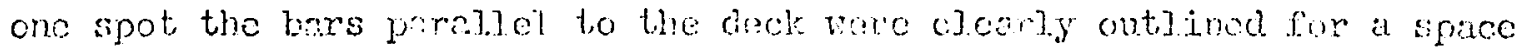
of 2 or $3 \mathrm{ft}$ cach wer. A close ingpetion of this arow showed that thon vess almost no concrote coverage. In sure pleoes the intordes acoth of

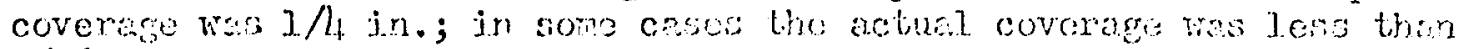
$1 / 16 \mathrm{in.}$ A disc of conerete 3 in. in diemolor and 0.7 in. thick wes cut from a fxigut colloctod in 1320, tosiod ju the J boratory, ond fourd to have vory lou vater pomeabitity (Itiditlan, 1928).

Simisen inspection reporls here beon recorded on other concrete ships bujlt during frorld ber. I. The "Solma," now stranded naen Galveston, lexes, was inspected and repocted on by Rogers at the 1953 licerionel Ioet..

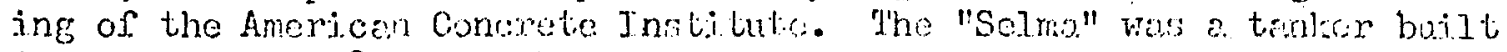

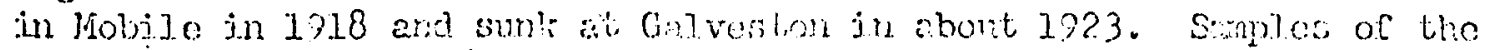

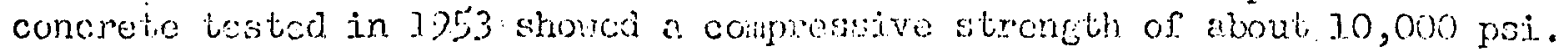
No corrosion of stce] was obsorved, even thougl Jess than 7 j.n. of cover was provided, Another of these vassols, the "palo $\Lambda 16$, is oxposed on

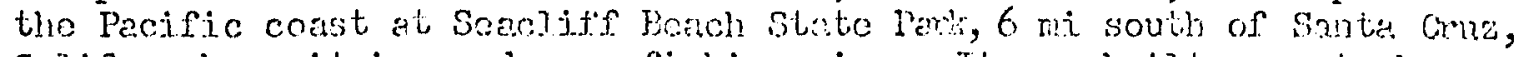
Colif., where it is used as a fishing pier. It wa built as a temker

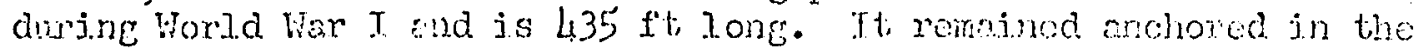

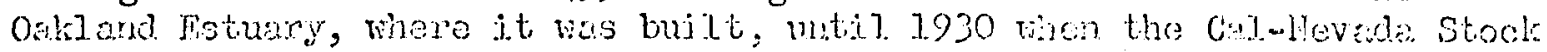

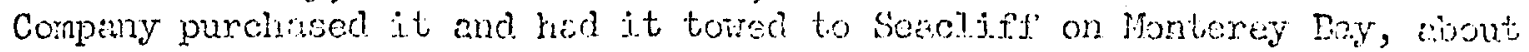
100 mi to tho south. The sea cooks wore opened ind it not rosts on ?

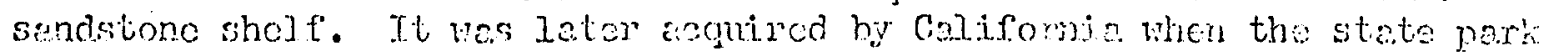
wes created. The ship has bioken j.ts boek, but a gingery ncross the fracture perinits both parts to be used. It is probably the most acososi... ble of the remining roxld ley $I$ conorete ships.

At the loth Congress of the Perinnent Troteriational dusociation of Navigation Congresscs, it wes "agreed that the deterioration of concrete in warn seatrator is minly due to chomicel action, namely, the change in composition of the cenent caused by the chlorides and sulphates present in the water. Lj.ttice can be done to protect, poor concrete, the renciy being to select a suitablo type of cemont and good sound ingrecotes in the fijst plice, and to take stops to ensure that the finished product is as dense and impermeable as pussible. In coloco vater, cluenical action is less severe and the min dangge is done by temporatiure cluanges. There are other couses of deteriountion, such as abrosion and acids deposited by lithofigous organisns" (Warren, 1956).

\section{CONCTUDING SAATEITIT}

From the forogoing discussion, ic might be assuned that it is the intent of this paper to sugeest thet jnformatjon is not avajleble winich vill pornit the preperation of specifications which, if followed, will preclude the occurrence of detorioretion of concrete cxposed to the sea. This is a proper conclusion with only relatively minor qualifications. if cost were not an important objective in preparing specifications for concrete, it rould certainly be possible to specify concreto matorjals, mixtures, and construction proctices which, if followed, would provico virtually complete assurance that deteriorition of the conoreto over any desired servir:e life, at lesst for up to joo yesrs, comle be avoided. In some cascs, however, such a specil'ication vould recpire the iriportam tion of largo quentities of materials from grest distiness ond would require a degree of testing, inspection, and controt that is not non: 
regarued as ocononicat jn conerete combluction. Ii therefore js

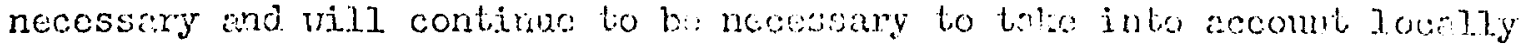

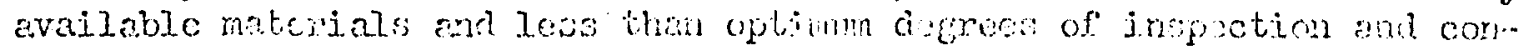
troj. This bojng the cose, the solme spocifjostion for rost conorota for cxposure to tho sea vith in some respects require materials and practices of loss then optimum quatily and the malorials and practices actusly obtained vil], to some crtent, be inferior to thit which res

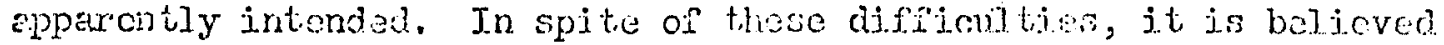
that through use of practicel spocifications ami protical inspoction and control moasuros deteriouation of concuete exposed to the sea can be kopt within limits so thnt only eccoptable majntensace costs wi]l. bo required. It may also be inferrod that the catiolor of dotierioretion producing pheromons is nor conplete. This, of coviso, is something about which it would be dongerous to mase a positive stetemont, erpecia].Jy since pherionena such as alkoli-carbonate rock reaction have coms to light onfy in the last few years. It is, howover, balieved that it is unlikely that thore are major deterioration-producing phonorena, the occurience of which is not reasonalily precluded by the imposition and enforcenent of current speciljeations. 
ACS (American Cherical Society), 196\% Chemistry as the Decan.

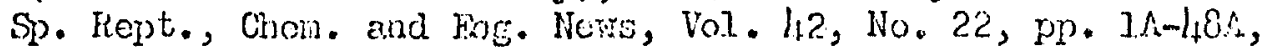
June 1 .

Buck, A1an D., and listher, Kotharine, 1969, Concrets Cores frun Diy

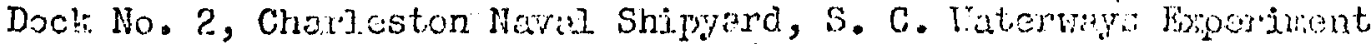
Station, fiscellanoous paper No. C-69-6, Vichsbure, Miss.

Curlson, R. Wo, 1937. Drying Shrinlese of Jinge Concroto Menbese proc. Ariericm Concrete Tnstibule, Vol. 33, p. 32\%.336.

Griffin, Dontd F., end Fengr, robrt J., 1964. The liffect of sat in Conerete on Compressive Strength, hater Vepor T'rensinision, and Corrosion of Reinforcint Stecl. U. S. Nave] Civir. Fngineoring Iob., Port Hucncine, Celifif., Teche Rejt. R 306.

Holstced, S., end Woodrorth, L. A., 1955. Tho Doterioretion of Heinforced Concrete Strutures Under Consten Conditjons. Trens. South Mrrican Inst. of Civil. Eng., Vol. 5, Apjil 1955; Nisc., Oet.

Kennedy, Thomes B., and Mather, Katherine, 1.953. Correlation Betteon Lakoratory Freezing end Thaving and Wothering at Treut InIand, Majne. Proc. ACI, Vol. 50, pp. 1/11-17?.

Lea, F. H., 3.956. The Chenistry of Cement and Concrete. Nev York, St. Nartin's Press, $637 \mathrm{pp}$.

Locher, F. W., and Pistera, H., 1964. Beurtojune betonangreifonden. Vasser. Zementwralk-Gips, 1No. 4, pp. 129-136, Aprill.

Mather, Bryant, 1957. Factors affecting durabijity of Concrete in Coastal Siructures. Beach Erosion Board, Orfice of the Chief of Engineers, Technical Kemorancium Ho. 96, Washingtion, D. C. $27 \mathrm{pp}$. with three appendices.

Mclillan, F. R., 1928. Concrete for the Architest. Illinois Soc. of Arch. Bull., pp. 4 .

Poivers, T. C., Copoland, I. E., and Mann, H. M., 1959. Capillary Contjnuity or Discontinuj.ty in Cemert Pastes. Jour. of Res. and Dev. Labs., Port. Cem. Assn., Vol. 1., No. 2, pp. 38m, 8 .

RILEI (Internation:l. Union of Testing and Reseanch L,borstories for Materjals and Scructures), 1.969. Prelinilnary Teport, Intcrnational Symposium-Imrability of Concrete - 1969. Frasue, Czochoslovalia, 2 Vol.

Terzaghi, Putl J), 1948. Concrete Deterication in a Sh: pray. Proc. ACI, Vol. Ih, pp. 977-1.005. 


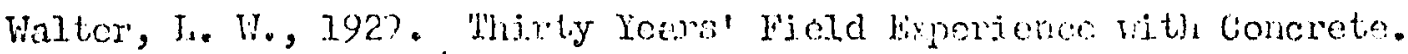
Proc. ACI, Vol. 25.

Worren, L. R., 1956. Swre Notes on the 1953 Conpresis of tho Pernanent Intornational Association of Navigation Congrosses. Irans. Souh

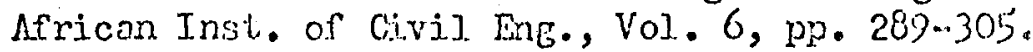

Wentworthwields, F. Fo, 1956. Barly Morine Structures. Concrete and Constr. Eng., Vol. 5l., No. 1, MI. 2', 29. 